\title{
Algılanan Hizmet Kalitesinin Algılanan Değer ve Tutumsal Marka Sadakati Üzerindeki Etkisinin İncelenmesi: 5 Yıldızlı Sayfiye ve Şehir Otelleri Örneği ${ }^{1}$
}

\author{
DOI: $10.26466 /$ opus.542994
}

*

Bülent Demirağ $\breve{g}^{*}$ Yakup Durmaz **

*Doktora Öğrencisi, Hasan Kalyoncu Üniversitesi, İşletme Anabilim Dalı, Gaziantep/Türkiye E-Posta: bulentdemirag@windowslive.com ORCID: 0000-0002-8718-1822 **Dr. Öğr. Üyesi, Hasan Kalyoncu Üni., İ̈BF., İşletme Bölümü, Gaziantep/Türkiye E-Posta: yakupdu@hotmail.com

ORCID: $\quad \underline{0000-0003-0332-4185}$

Öz

Marka sadakati ve marka sadakatinin öncülleri olarak kabul edilen kavramlar üzerine son dönemlerde gerçekleştirilen çalışmalar ve elde edilen sonuçlar konunun değişik sektörlerde incelenmesi yönünde bir fikir sunmaktadır. Bu çalışmanın amacı, algılanan hizmet kalitesinin algılanan değer ve tutumsal marka sadakati üzerindeki etkisinin incelenmesidir. Araştırmanın örneklemini Ankara ve Antalya illerinde beş yıldızl sayfiye ve şehir otellerinde konaklayan 450 otel müşterisi oluşturmaktadır. Nicel araştırma yönteminin kullanıldı̆̆ı bu araştırmada veri toplama tekniği olarak anket kullanılmıştır. Ankette; algılanan hizmet kalitesi, algzlanan değer ve tutumsal marka sadakati değişkenlerini ölçmeye yönelik ifadelerin yanı sıra, turistlerin otel deneyimlerine ilişkin ifadeler ile demografik özelliklere ilişkin ifadelere yer verilmiştir. Toplanan veriler SPSS ve AMOS programlarıla analiz edilmiştir. Elde edilen bulgular, algılanan hizmet kalitesinin boyutlarından empatinin algılanan değer ile ve algzlanan hizmet kalitesinin boyutlarından heveslilik ve güvencenin tutumsal marka sadakati üzerinde etkisinin olduğu göstermiştir. Ayrıca algzlanan değerin tutumsal marka sadakati üzerinde pozitif ve doğrudan bir etkisinin olduğunu yapılan analizler sonucunda tespit edilmiştir.

Anahtar Kelimeler: Algılanan hizmet kalitesi, Algılanan değer, Tutumsal marka sadakati, Şehir ve Sayfiye otelleri

\footnotetext{
${ }^{1}$ Bu çalışma, Hasan Kalyoncu Üniversitesi Sosyal Bilimler Enstitüsü tarafından yürütülmekte olan doktora tezinden türetilmiştir.
} 


\title{
Investigation of the Effects of Perceived Service Quality on Perceived Value and Attitude Brand Loyalty: Five-Star Resort and City Hotels Example
}

\begin{abstract}
The recent studies on the concepts that are accepted as the forerunners of brand loyalty and loyalty, and the results obtained, provide an idea to examine the subject in different sectors.The aim of this study is to investigate the effect of perceived service quality on perceived value and attitudinal brand loyalty. The sample of the study consisted of 390 hotel customers staying in five stars hotels and city hotels in Ankara and Antalya. The questionnaire was used as a data collection technique in the study which was used quantitative research method. In addition to statements about perceived service quality, perceived value and attitude brand loyalty variables, surveys about hotel experiences and demographic characteristics were included in the survey. The collected data were analyzed with SPSS and AMOS programs. The findings show that empathy has an effect on perceived value of perceived quality of service, and on the attitudes of perceived quality of service and enthusiasm and assurance on attitude brand loyalty. In addition, it was determined that the perceived value had a positive and direct effect on attitude brand loyalty.
\end{abstract}

Keywords: Perceived service quality, Perceived value, Attitudinal brand loyalty, Resort and city hotels 


\section{Giriş}

Markanın, firmalar açısından taşıdığı öneme ilişkin algının güçlenmesi, son yıllarda marka konusunda turizm sektöründe birçok çalışmanın yapildığı gözlemlenmektedir (Mason vd., 2006; Mattila, 2006; O’Neill vd., 2006). Bu çalışmalardan önemli bir bölümü marka sadakati ve marka sadakatini oluşturan öncüller üzerinde yoğunlaşmıştır. Literatüre yönelik çalışmalarda marka sadakati ve marka sadakatinin öncülleri olan algılanan hizmet kalitesi, algılanan değer kavramlarına yönelik ayrıntılı çalışmalara rastlanılmaktadır (Back ve Parks, 2003; Han vd., 2008; Chitty vd., 2007; Kayaman ve Araslı, 2007). Bu çalışmaların sayısını çoğaltmak gerekmektedir. Zira marka sadakati kavramı ve bu kavramla doğrudan ve dolaylı etkisi olduğu düşünülen birçok marka bileşeni değişik kültür ve coğrafyalarda incelenmeye devam edilmektedir (Brodie vd., 2009; Cronin vd., 2000; Dick ve Basu, 1994; Oliver, 1997).

Markaya ilişkin önemli bir kavram olan algilanan değer ile marka sadakati arasındaki ilişkileri inceleyen çalışmalar (Oh, 1999; Cronin, 2000; Chitty vd., 2007; Şener ve Behdioğlu, 2013), müşterinin algıladığı marka değeriyle sadakat seviyeleri arasında önemli ilişkiler tespit etmişlerdir. Yapılan çalışmalar, tüketicilerin fayda - ödün değerlendirmesinin bir sonucu olan algılanan değer kavramının (Zeithaml, 1988) ayrıntılarıyla incelenmeden marka sadakatine ilişkin stratejiler geliştirmenin eksiklik olacağı yönünde bulgular ortaya çıkarmıştır. Öte yandan, sadakatin bir başka öncülü olarak değerlendirilen algılanan hizmet kalitesi ile marka sadakati arasında ilişkileri ortaya koyan önemli çalışmalar bulunmaktadır. (Usta ve Memiş, 2009; Ertürk, 2011; Kayaman ve Araslı, 2007; Alhaddad, 2015; Souki ve Filho, 2008). Özellikle eşanlı değiş-tokuşun yaşandığı ve de deneyime dayalı satın almanın çok da mümkün olmadığı, turizm gibi hizmet endüstrilerinde, bu kavramların gerçek anlamlarını ortaya çıkarmak ve nihayetinde araştırmanın da bir parçası olan marka sadakati üzerindeki etkilerini değişik kültür ve coğrafyada incelemek önem arz etmektedir. Zira DeWulf vd. (2001, s.34), bir ortamda yaratılan modelleri diğer farklı durumlarla (ülke ve endüstri koşullarında) incelemelerle doğrulamaya ihtiyaç olduğunu belirtmişlerdir. 
Turizm; kültürlere, ekonomilere ve toplulukların sosyal yaşamlarına yerleştirilen mekânlar ile ilgilidir (Saraniemi ve Kylänen, 2011, s.133). Turizm, geniş anlamda, mevcut konaklama tesislerinin niteliğine ve miktarına bağlıdır. Konaklama işletmeleri turizmin gelişmesinde çok önemli bir faktördür (Tunç ve Sevin, 2000, s.764). Konaklama işletmeleri içerisinde otel işletmeleri sahip olduğu olanaklar ve niceliksel üstünlüklerinden dolayı en önemli konaklama işletme türü olarak dikkat çekmektedir. Otel "uyumak için bir odanızın olduğu ve yemek yiyebileceğiniz ya da kısa süreli olarak ücretli konaklama imkânı sağlayabildiğiniz bir kurum" olarak ifade edilebilir (Bresciani vd., 2015, s.22). Tsai vd., (2009, s.537), otelleri, girdi faktörlerini kullanarak turistler için çeşitli ürün ve hizmetler (çıktılar) üreten kurumlar olarak değerlendirmektedirler.

Turistler, ziyaret ettikleri alanda değişik ihtiyaç ve isteklerini gidermek isterler. Turistlerin konaklama ve diğer ihtiyaçlarını gidermek amacıyla planlanan turistik faaliyetler bir bütün olarak düşünülmeli ve tüm özellikleri ve bölümleri turistlerin ihtiyaçlarına göre incelenerek değer önerisi sunulmalıdır (Seyidov ve Adomaitienè, 2016, s.114). Crompton (1979), literatürde yüzeysel incelenen iş ve tatil amaçlı turist olma motivasyonunu daha da özelleştirerek yedi farklı turist ziyaret nedeni tipolojisi belirlemiştir. Bunlar; yenilik (novelty), sosyalleşme (socialization), prestij (prestige), dinlenme ve rahatlama (rest and relaxation), eğitim değeri yaratma (education value), aile birlikteliği (family togetherness) ve geri çekilme (regression) olarak tasnif edilmektedir. Bunlar içerisinde yenilik, dinlenme ve geri çekilme daha çok turist keyfiliğini içerirken, diğer nedenler bir zaruriyeti içermektedir (Becker, 2014, s.22). Bu nedenle otel işletmeleri turist beklentilerine bağlı olarak sınıflandırmaya tabi tutulmaktadır. Bu kapsamda otel işletmeleri, tüketicilerin günlük ihtiyaçlarına yönelik tüm talepleri (yeme, içme, uyuma, dinlenme vs.) karşılamakla yükümlü oldukları gibi spor, eğlence, animasyon, kültür ve sanat etkinlikleri gibi ihtiyari ihtiyaçları da karşılamak zorundadır. Bu noktada tüketicilerin konaklama işletmesinden spesifik fayda beklentileri önemli olmaktadır. Bu yüzden otel işletmeleri şehir oteli, dağ oteli, termal otel ve say fiye oteller gibi farklı türler olarak incelenmektedir. Ünüvar (2008, s.14), şehir otellerini; şehir merkezlerinde ya da özellikle büyük şehirlerde iş ve ticaret hayatının yoğun olduğu merkezlerde veya merkeze yakın yerlerde konumlanan ve çoğunlukla yıl boyu hizmet veren işletmeler olarak tanımlamaktadır. Bir 
başka tanıma göre şehir otelleri; şehir merkezlerinde konumlanan ve daha kısa süreli konaklamaların gerçekleştirildiği otellerdir (Çetiner, 2002). Genç ve Erdoğan (2013, s.197) tarafından da ifade edildiği gibi sayfiye oteller, say fiye turizminin yoğun olarak yaşandığ turizm bölgelerinde konuşlanmıştır. Sayfiye oteller; turistlerin tatil, sağlık, eğlence ve dinlenme gibi ihtiyaçlarını karşılayan konaklama işletmeleridir (Emir, 2007, s. 24). Sayfiye otellere ilişkin literatür değerlendirmelerinde bu kavramın kıyı/resort oteller ya da sayfiye işletmeleri olarak da adlandırıldığı görülmektedir (Kılıç ve Öztürk, 2010, s.990; Kozak, 2008). Sayfiye otel işletmelerinin sahip olduğu özellikler nedeniyle, turistlerin en az 10 gün konaklayacakları düşünülmektedir. Bu yüzden bu türdeki otel işletmelerinin konaklayanlara değişik özellikte eğlence ve animasyon hizmetleri sunmaları zorunlu gözükmektedir (Dinç, 1999, s.53).

Bu doğrultuda çalışma kapsamında, literatüre yönelik kapsamlı değerlendirmelerden yola çıkılarak otel türleri içerisinde oldukça önemli bir yer tutan şehir otelleri ve sayfiye otellerden toplanan verilerle, algilanan hizmet kalitesi, algilanan değer ve tutumsal marka sadakati arasındaki ilişki incelenmiştir. Çalışmanın olgunluk dönemini yaşayan turizm sektöründe gerçekleştirilmesindeki amaç, rekabetin yoğun yaşandığ ${ }_{1}$ bu sektörde firmalara marka stratejileri geliştirmeleri açısından rekabet avatajı yaratabilecek öngörüler sunulmak istenmesidir. Bu durum çalışmayı önemli kılmaktadır.

\section{Kavramsal Çerçeve}

\section{Algılanan Hizmet Kalitesi}

Algılanan hizmet kalitesi, tüketicilerin beklentileri ve algıları arasındaki farka ilişkin bir değerlendirmedir. Beklentiler, tüketiciler tarafından bir hizmet sağlayıcının sunması gerektiğine inanılan isteklere yansır. Beklentiler, algılanan kalite ile uyumlu değilse, ürüne firmaya yönelik olumsuz değerlendirmeler oluşur. Ancak, algılanan kalite beklentileri aşmışsa firma kazanımı sağlanmıştır (Lovelock ve Wright, 2007). Zeithaml vd.(1990), algılanan hizmet kalitesini bir firmanın müşterinin amacına başarıyla hizmet ettiği ölçü olarak ifade etmiştir. Parasuraman vd., (1988, s. 
15), müşterilerin hizmet kalitesini farklı şekillerde algıladıklarını ileri sürmektedir. Birinci seviye, müşterinin servis sağlayıcı tarafından almayı umduğu hizmet seviyesi olan beklenen/istenen hizmettir. İkinci seviye, müşterinin kabul edeceği hizmet seviyesi olan yeterli hizmettir. Müşteri açısından hizmetin fayda yaratması durumu, ürüne ilişkin mükemmellik algısıdır. Bu algı, tüketicilerin ürünü her kullanımda daha fazla beklenti karşılamasıyla oluşur. Fayda, hizmetin beklenenden daha kötü olması durumunda daha belirgin hissedilir ve bu durum işletme açısından olumsuz sonuçlar yaratır (Casadesus vd., 2002, s.1001).

Hizmet kalitesinin ölçümünde literatürde farklı endüstriler açısından farklı ölçüm modelleri geliştirilmiştir. Bununla beraber, literatürde en sık yararlanılan ölçüm modelinin Açıklık Modeli-SERVQUAL Ölçüm Modeli olduğu bilinmektedir. Parasuraman vd. (1985) yılında, algılanan hizmet kalitesine ilişkin beşli boşluk modellemesinin ardından, tüketicinin kaliteyi yorumlarken kullandığı hizmet kalitesi belirleyicilerinden yola çıarak on boyutlu (güvenilirlik, heveslilik, yetkinlik, ulaşılabilirlik, nezaket, iletişim, dürüstlük, güvenlik, müşteriyi anlamak, somut özellikler) bir ölçüm modeli belirlemiş daha sonra 1990 yılına uzanan süreçte, farklı endüstrilerde bu modeli test ederek (somut özellikler, heveslilik, güvenilirlik, güvence ve empati) olarak uluslararası kabul gören beş boyutlu bir ölçüm modeli ortaya koymuşlardır. Modelde tüketicilerin hizmete ilişkin beklentileri ölçülmüş, hizmet kalitesi tanımı ve kavramsal çerçevesi tüketici beklentilerine uygun bir model yardımıyla farklı boyutlar içeren Servqual ölçeğini oluşturmuştur (Bozdağ vd., 2003, s.4). SERVQUAL ölçeği, tüketicilerin hizmete ilişkin beklentileri ile algılanan hizmet kalitesine ilişkin ilişkiyi ifade etmektedir. Bu kapsamda:

Beklenen Hizmet > Algılanan Hizmet ise; tüketicilerin sunulan hizmetten algıladıkları kalite, tüketici tatmini oluşturmaz.

Beklenen Hizmet = Algılanan Hizmet ise; tüketicilerin sunulan hizmetten algıladıkları kalite tüketici tatmini yaratır.

Beklenen Hizmet < Algılanan Hizmet ise; tüketicilerin sunulan hizmetten algıladıkları kalite tüketici tatmini yaratır, aradaki fark büyüdükçe ideal kaliteye yaklaşılır (Parasuraman vd., 1985). SERVQUAL modelinin geliştirilmesine yönelik çalışmada (Parasuraman vd. 1988; 1991 ve 1993), modelin güvenilirlik ve geçerlilik açısından yeterli, anlaşılırlık açısından ise basit ve kapsamlı çok boyutlu ölçme aracı sunduğunu belirtmişlerdir. 


\section{Algılanan Değer}

Algılanan değer, müşteriler tarafından ürün/hizmetin kullanmasına yönelik fayda/ödün karşılaştırmasına dayalı olarak oluştuğunu işaret etmektedir (Bhattacharya ve Singh, 2008; Gale, 1994). Algilanan değer, tüketicinin, yararını ve ödediğini algılamaya yönelik bir değerlendirmedir. Genel olarak tüketicilerin maliyetleri (satın alma fiyatı, satın alma maliyetleri, kurulum) kapsar, algılanan faydalar ise ürünün/hizmetin fiziksel ve soyut özelliklerinin kombinasyonlarının yararlı olmasıdır (Varki ve Colgate, 2001, s.234). Müşteriler genellikle faydaları ve maliyetleri doğru ya da nesnel olarak değerlendirmezler, aksine ürünün algılanan değerine göre hareket ederler. Bu nedenle firmalar, müşterilerin kalite algılarını ve değer yargılarını kontrol edebilmelidirler (Baker ve Fulford, 2016, s.76). Zeithaml (1988), algılanan değeri fedakârlıklar olarak nitelendirmekte ve bu fedakârlıkların parasal olmayan fırsat maliyetlerini de içerdiğini belirtmektedir. Ayrıca, algılanan değerin algılanan kaliteden iki noktada farklılık yarattığını ifade etmektedir. Birincisi, algılanan değer, daha bireysel ve daha fazla kişisel özniteliklere bağlı olan üst düzey soyutlamalara bağlıdır. İkincisi, değer, ürünün faydalarının, satın alma veya kullanımdan kaynaklanan maliyetlere karşı ağırlıklandırıldığı bir zorunluluk olarak kabul edilir. Ancak, kalite sadece tüketicilerin satın alma kararlarından umdukları fayda değildir, örneğin saygınlık (prestij) gibi faktörler de olası faydalar olarak sayılabilir.

Algılanan değer kavramının boyut olarak ölçümüne yönelik ilk çalışmanın Zeithaml (1988) tarafından gerçekleştirildiği bilinmektedir. Park vd. (1986), müşteri değeri türlerini araştırırken, üç temel müşteri gereksinimini öne sürmüştür. Sanchez vd. (2006), turizm alanındaki çalışmalarında müşteri değeri kavramının en kapsamlı sınıflandırmasını yapmakta ve iki müşteri algılanan değer kavramsallaştırmasını tanımlamaktadır. Birincisi, müşteri değerini fiyat temelli çalışmalara ve araç-amaç teorisine dayanan tek boyutlu bir yapı olarak tanımlar (Zeithaml, 1988). İkincisi, birbiriyle ilişkili boyutlardan oluşan ve faydacı ve hedonistik değere odaklanan çok boyutlu bir yapı olarak tüketici değerini ele alır (Holbrook, 1996, s.140). Cronin vd. (2000), farklı hizmet endüstrilerinde (fast-food, sağlık, spor) gerçekleştirdikleri çalışmada, Zeithaml (1988)'in hizmet değerine ilişkin 
yaklaşımlarından ve ölçüm modellerinden yararlanarak algılanan değeri iki değişkenle ölçmüştür. Buna göre algılanan hizmet değeri tek boyut altında (parasal değer) iki faktörde incelenmiştir. Wang vd. (2016), turist tatmini ve algılanan değerin destinasyon imajı ve sadakat üzerindeki aracılık rolünü inceledikleri çalışmalarında algılanan değeri zaman değer, ve parasal değer olmak üzere iki değişkenle incelemişlerdir. Zaman değeri, müşterilerin hizmetlerden yararlanmak için gösterdikleri çabaların bir sonucu olarak (parasal olmayan değer) değerlendirilirken, parasal değer, hizmetler için ödenen bedel olarak ifade edilmektedir. Zeithaml (1988)'de önerilen ölçüm modelinde belirtildiği üzere fayda-ödün değerlendirmesi çalışmada müşteri değerini belirleyen bir unsur olarak ele alınmıştır. Algılanan değeri ölçmek adına, Turizm alanında algılanan değer kavramının ölçümüne yönelik değişik ölçüm modelleri sunan aynı zamanda marka sadakati ve öncülleri ile ilişkilerini açıklayan çalışmaların sayısını çoğaltmak mümkündür (Bowen ve Shoemaker, 2003; Chitty vd., 2007; Wang vd., 2004; Nasution ve Mavondo, 2008).

\section{Marka Sadakati}

Marka sadakati, herhangi bir işletme için sürdürülebilir bir rekabet avantajı geliştirmek için önemli bir stratejidir (Dick ve Basu, 1994). Oliver (1997;1999) marka sadakatini "durumsal etkilere veya pazarlama çabalarnna rağmen, gelecekte tercih edilen bir ürünü veya hizmeti sürekli olarak tekrar satın almak veya yeniden değerlendirmek için derinlemesine bir bağlllık" olarak tanımlamıştır. Day (1969), marka sadakatinin ilk aşamasında müşterinin, bir hizmet sağlayıcıdan ya da tedarikçiye karşı, yapılan işlem sonucunda psikolojik olarak bağlılık yaşayacağını ve bu durumun da tekrarlanan satın almaların eylemsel yönünü oluşturacağını belirtmektedir. Newman ve Werbal (1973, s. 405)'de benzer bir tanımlama ile marka sadakatine yönelik değerlendirmelerini bağlılık sonucu oluşan güvene dayandırmaktadır. Buna göre, markaya ilişkin sadakatin ön koşulu markayı kullanan müşterilerin tekrarlayan ürün/hizmet kullanımlarında deneyime yönelik satın alma davranışı sergilemeleridir.

Marka sadakatinin ölçümüne yönelik geleneksel tek boyutlu yaklaşım, sadakatin tutum ve/veya davranış boyutları dikkate alınarak ölçülmesi yönündedir (Brodie vd., 2009; Cronin vd., 2000; Dick ve Basu, 1994; Oliver, 
1997). Bununla birlikte, bu iki boyut, marka sadakatinin karmaşıklığını ve dinamikliğini tatmin edici bir şekilde açıklayamamaktadır (Oliver, 1999). İlk araştırmacılar marka sadakatinin çok boyutlu olmasının varlığını ifade etmişlerdir (Dick ve Basu, 1994; Jacoby ve Chestnut, 1978). Jones ve Taylor (2007) ve Lee vd., (2007) çalışmaları, marka sadakatinin çok boyutlu varlığını desteklemektedir. Literatürde markaya yönelik tutumsal sadakatin alt boyutlarının, zamanla eylemsel yönü ifade eden ve satın almayı sağlayan davranışsal sadakate yol açtı̆̆ı vurgulanmaktadır (Dick ve Basu, 1994). Ancak, öncül çalışmalar (Cunningham, 1956; Tucker, 1964), genellikle sadakati tek taraflı davranışsal boyutta incelemek konusunda birleşmektedir. Öte yandan, (Odin vd., 2001) gibi yazarlar, sadakati bir tutum olarak kavramsallaştırmaktadırlar. İlk araştırmacılar (Dick ve Basu, 1994; Jacoby ve Chestnut, 1978) geleneksel marka sadakati yaklaşımlarını tutum ve davranış olarak karma (tutum ve davranış birlikte) yöntem uygulamanın daha yararlı olacağını belirtmişlerdir.

Sadakati iki boyutuyla ele alan ilk araştırmacılardan olan Day (1969), marka sadakatinin davranışsal olduğu kadar, tutumsal temelde de değerlendirilmesi gerektiğini ifade ederek Oliver $(1997 ; 1999)$ çalışmalarında tutumsal marka sadakatinin bileşenlere ayrılarak incelenmesinin temelini oluşturmuştur. Oliver'ın (1997 ve 1999) çalışması, tutumsal marka sadakatinin bileşenleri olarak bilişsel (cognitive) sadakat, duygusal (affective) sadakat, çabasal (conative) sadakat sadakatten oluşan çok boyutlu bir marka sadakatini literatüre kazandırarak geleneksel tek boyutlu ve karma yaklaşımları bir adım öteye taşımıştır. Bu durum, marka sadakatinin salt davranış ya da tutum olarak ölçülmesi fikrinde değişiklikler yaratmıştır. Oliver $(1997 ; 1999)$ çalışmaları marka sadakatinin çok boyutlu varlığını desteklemektedir. Harris ve Goode (2004), Oliver'ın çok boyutlu kavramsallaştırmanın marka sadakatinin en kapsamlı değerlendirmesi olduğunu ifade etmişlerdir. Oliver, tutumsal marka sadakati oluşumunda bilişsel sadakatin sadakat geliştirmede ilk aşama olduğunu, duygusal ve çabasal sadakatin ise bu aşamadan sonra oluştuğunu belirtmektedir. Oliver tüketicinin ilk üç aşamada markaya karşı tutumlar geliştirdiğini, dördüncü aşamada ise satın alma olarak gözlemlenen davranışsal sadakat ile sürecin sona erdiğini belirterek, geleneksel yaklaşımların eksiklik ve eleştirilerini oldukça azaltmıştır. Oliver $(1997,1999)$ sadakati, Jacoby ve Chestnut (1978)'a benzer şekilde açıklamaktadır. Araştırmacı marka sadakatinin 
kavramsallaştırılmasını, sadakatin ne ikili bir sistemle (sadakat veya sadakat değil) ne de çok kategorili tipoloji (örneğin düşük, sahte, gizli ve yüksek sadakat) olmadığını, ancak bir sıra veya sürekliliği ifade etmektedir. $\mathrm{Bu}$ durumda sadakat formülasyonu bilişsel sadakat ile başlar, ardından duygusal sadakat, çabasal (gayret ifade eden) sadakat veya niyet sadakati ve son olarak fiili satın alma (eylem sadakati veya davranış sadakati) ile sonuçlanır (Oliver, 1997, s.392). Bilişsel sadakat, tüketicilerin yararlandıkları ürün bilgilerine dayanmaktadır (Yüksel vd., 2010, s.277). Bir müşteri başlangıçta yalnızca marka niteliği hakkındaki inançlara dayanarak bilişsel olarak sadık olur. Marka performansının beklentilere uygun şekilde yerine getirilmesiyle duygusal sadık hale gelir. Sonunda, markaya özgü bir taahhüt gösteren, markaya ulaşmak için çaba harcayan sadık bir müşteri kitlesi oluşur. Başka bir deyişle, marka sadakati, müşterinin tercihi ve belirli bir markaya bağlılı̆̆ını içermektedir (Back, 2005, s.451). Oliver (1997, s.35), gerçek bir marka sadakatinin oluşumu için üç koşul öne sürmektedir. Buna göre ilk koşul, markanın niteliklerine yönelik tutumun (inançların) oranının rekabetçi tekliflere yönelik tutumlardan daha fazla olmasıdır. İkinci olarak markaya yönelik sahip olunan bilişsel fonksiyonların duygusal bir tercihle (tutumla) örtüşmesi gerekir. Son olarak tüketici, alternatiflerle kıyaslandığında satın alma tercih listesinde güçlü bir tutuma sahip markaya yönelik çabasal niyete sahip olmalıdır. Bilişsel, duygusal ve çabasal sadakat aşamaları esasen tüketici içsel zihinsel süreci ile ilgilidir ve kendini dışa vurmaya eğilimli değildir. Öte yandan, davranışsal sadakat daha dişsal olarak sadakat eylemlerini ifade ederek tutumsal bileşenleri oluşturan bilişsel, duygusal ve çabasal marka sadakati seviyelerinin dışa vurumuna aracı olur (Hinson ve Chinje, 2016, s.55).

\section{Kuramsal Çerçeve}

Literatürde değişik hizmet sektörlerinde algılanan hizmet kalitesi ile alg1lanan değeri inceleyen çalışmalara rastlanılmaktadır. Algılanan değerin kavramsal tanımı, değerin "tüketicinin, ne elde edildiğine ve ne verildiğine ilişkin algılarına dayanarak bir ürünün kullanımına ilişkin genel değerlendirmesi" olarak tanımlanmasına dayanır (Zeithaml, 1988, s.14). Değer, tüketici eylemlerini sadakatin davranışsal niyetleri düzeyinde düzenleyen bir tüke- 
tici hedefidir (Sirdeshmukh vd., 2002). Önceki araştırmalar, algılanan değerin niyeti (Kim vd., 2008; Oh, 1999; Petrick, 2004), bağlılığ1 (Pura, 2005) ve marka sadakatini (Chen ve Hu, 2010; Sirdeshmukh vd., 2002) etkilediğini göstermektedir. Bir müşterinin sadakat seviyesi, ürün ve hizmetlerin kalitesinin algılanan değerine (Brodie vd., 2009; Cronin vd., 2000) bağlıdır. Algılanan hizmet kalitesi, algılanan değer, markaya yönelik tutum ve davranışlar arasındaki ilişkileri değişik hizmet sektörlerinde inceleyen çalışmalar, marka sadakati öncülleri olarak kabul edilen bu kavramların ayrintılarıyla incelenmesi konusunda fikirler sunmaktadır ( Ladhari ve Morales, 2008; Leonnard, 2018; Raza vd., 2012; Choi vd., 2018; Brodie vd., 2009; Cronin vd., 2000; Zeithaml vd., 1996).

Alanyazında hizmet kalitesi, algılanan değer ve marka sadakati boyutlarının turizm sektöründe incelenmesine yönelik çeşitli çalışmalara rastlamak mümkündür (Kayaman ve Araslı, 2007; Kandampully ve Hu, 2007; Kement ve Güçer, 2015; Jasinskas vd., 2016). Bazı çalışmalar, algılanan değerin (Sweeney ve Soutar, 2001) ve algilanan hizmet kalitesinin (Alexandris, vd., 2006) müşteri sadakati üzerinde doğrudan etkisi olduğunu göstermektedir. Öte yandan, Kandampully ve Hu (2007), turizm alanında hizmet kalitesi ile marka sadakati arasında anlamlı bir ilişki tespit edememiştir. Kayaman ve Araslı (2007) ve Kim vd. (2008), hizmet kalitesinin sadece fiziksel özellikler ve heveslilik boyutlarının marka sadakati üzerinde etkisinin olduğunu, diğer boyutlarda böyle bir etkiye rastlanılmad1ğını rapor etmişlerdir. Han vd. (2008), Çin'de iki otel işletmesinde gerçekleştirdikleri çalışmada, hizmet kalitesinin tutumsal marka sadakatinin ilk aşaması olan bilişsel marka sadakati boyutunda etki yarattığını, diğer bütünleşik sadakat boyutlarında ise herhangi bir etkiye rastlanılmadığını rapor etmişlerdir. Jasinskas vd. (2016), Litvanya Kaunas bölgesinde dört yıldızlı otellerde konaklayan 205 turist üzerinde gerçekleştirdikleri çalışmada, turistlerin beklenen kalite ile algıladıkları kalite arasındaki farkın az olması durumunun marka sadakat düzeylerinde belirgin bir etki yarattığını ortaya koymuştur. Günaydın (2015), Bodrum Aegean Dream Hotel'de hizmet kalitesi ile müşteri sadakati arasında güçlü bir ilişki tespit etmiştir. Ashraf vd. (2018), hastane, otel, eğitim ve bankacılık hizmet sektörlerinde 440 müşteri ile gerçekleştirdikleri çalışmada algılanan hizmet kalitesi ve algılanan değerin marka sadakatine etkisini araştırmışlar, hiz- 
met kalitesinin ve algılanan değerin marka sadakatini etkilediğini, müşteri tatmininin aracı etkiye sahip olduğunu belirtmişlerdir. Lai (2014), seyahat acentalarındaki turistlere yönelik çalışmalarında hizmet kalitesi, algılanan değer ve ilişki kalitesinin müşteri sadakati üzerindeki rolünü araştırmışlardır. Çalışmanın bulguları, hizmet kalitesi ve algılanan değerin ilişki kalitesinin öncülü olduğunu, ilişki kalitesinin üç boyutunun ise (müşteri memnuniyeti, müşteri güveni ve müşteri taahhüdünün) müşteri sadakati üzerinde önemli bir etkisinin olduğunu rapor etmektedir. Suhartanto ve Noor (2013), Endonezya' da ekonomik otellerde konaklayan 399 turist üzerinden gerçekleştirdikleri çalışmada algılanan hizmet kalitesi ve hizmetten algıladıkları değerin tutumsal marka sadakati üzerindeki etkisini araştırmışlardır. Çalışmada (s.66), tutumsal marka sadakatinin ölçüm olarak kullanılmasının nedenini; müşterileri "çok sadıktan"'"az sadığa" doğru tanımlama olanağına sahip olması ve gelecekteki davranışları tahmin etme kolaylığından kaynaklandığı ifade edilmiştir. El-Adly (2018), otellerde konaklayan turistler üzerinde algılanan değer, tatmin ve tutumsal marka sadakatinin bilişsel ve duygusal boyutları arasındaki ilişkiyi incelemiş, algılanan değerin özellikler, işlem, kalite, fiyat ve kişisel hoşnutluk boyutlarının tatmin ve tutumsal marka sadakati üzerinde doğrudan olumlu bir etkiye sahip olduğunu, estetik ve prestij boyutlarının ise doğrudan ve pozitif bir etkiye sahip olmadığın belirlemiştir. Hapsari vd. (2016), Endonezya'daki havalimanında 200 turistten topladıkları verilerde, algılanan hizmet kalitesinin algılanan değer ve müşteri tatmini üzerinde güçlü bir etkiye sahip olduğunu bulmuşlardır. Arpacı ve Batman (2015) çalışmasında, helal otel kategorisinde yer alan dört ve beş yıldızlı otellerde konaklayan 400 turistten topladıkları verilerde, algılanan hizmet kalitesi, algılanan değer ve tutumsal ve davranışsal sadakat sorularından oluşan marka sadakati arasında güçlü bir ilişkinin olduğunu tespit etmişlerdir. Chen ve Chen (2010), deneyim kalitesi ile algilanan değer arasındaki ilişkiyi inceledi. Bulguları, ziyaretçilerin miras turizminden edindiği deneyim kalitesi algılarının, değer algılarını belirlediğini gösterdi. Krasna (2008), Slovenya' da otellerde konaklayan müşteriler üzerinden gerçekleştirdiği çalışmada algılanan değerin müşteri sadakati üzerindeki etkisini araştırmıştır. Çetintürk (2017), üniversite sosyal tesislerinde konaklayan 270 müşteriye yönelik çalışmada müşterilerin algılanan değeri, tatmin ve marka sadakati arasında güçlü bir ilişki tespit etmiştir. Milfelner vd. 
(2011), Slovenya ve İtalya' daki turistler üzerinde gerçekleştirdikleri çalışmada, algılanan hizmet kalitesi ile algılanan değer arasında güçlü ve pozitif bir ilişkinin olduğunu belirtmişlerdir.

Bu bulgular 1şığında aşağıdaki hipotezler geliştirilmiştir.

- H1a. Algilanan hizmet kalitesinin fiziksel özellikler boyutu algilanan değeri pozitif ve doğrudan etkilemektedir.

- H1b. Algılanan hizmet kalitesinin güvenilirlik boyutu algılanan değeri pozitif ve doğrudan etkilemektedir.

- H1c. Algulanan hizmet kalitesinin heveslilik boyutu algzlanan değeri pozitif ve doğrudan etkilemektedir.

- H1d. Algzlanan hizmet kalitesinin güvence boyutu algzlanan değeri pozitif ve doğrudan etkilemektedir.

- H1e. Algzlanan hizmet kalitesinin empati boyutu algzlanan değeri pozitif ve doğrudan etkilemektedir.

- H2. Algilanan değer, tutumsal marka sadakatini pozitif ve doğrudan etkilemektedir.

- H3a. Algilanan hizmet kalitesinin fiziksel özellikler boyutu tutumsal marka sadakatini pozitif ve doğrudan etkilemektedir.

- H3b. Algulanan hizmet kalitesinin güvenilirlik boyutu tutumsal marka sadakatini pozitif ve doğrudan etkilemektedir.

- H3c. Algzlanan hizmet kalitesinin heveslilik boyutu tutumsal marka sadakatini pozitif ve doğrudan etkilemektedir.

- H3d. Algilanan hizmet kalitesinin güvence boyutu tutumsal marka sadakatini pozitif ve doğrudan etkilemektedir.

- H3e. Algilanan hizmet kalitesinin empati boyutu tutumsal marka sadakatini pozitif ve doğrudan etkilemektedir.

\section{Yöntem}

\section{Araştırma Modeli}

Araştırmada kullanılacak ölçeklerin cümle yapıları uzman görüşleri doğrultusunda veri toplamak için uygun hale getirilmiştir. Ölçekleri oluşturan ifadelerin tümü 5'li likert tipi soru formatında sorulmuştur. Bu bağlamda 5'li likert tipi ölçeği (Kesinlikle Katılmıyorum =1, Kesinlikle Katıl1- 
yorum=5) kullanılarak dereceli sınıflandırılmış toplam 35 soruya yer verilmiştir. Anketin ilk bölümünde algılanan hizmet kalitesini içeren 22, algilanan değeri içeren 4 , tutumsal marka sadakatini içeren 9 soru yer almaktadır. Anket formunun son bölümünde ise araştırmaya katılanlar hakkında tanımlayıcı bilgiler elde edilmesi amacıyla demografik sorular, otel deneyimine ilişkin sorular ve otel tercihinde etkili olan faktörlere ilişkin sorular bulunmaktadır.

Algılanan hizmet kalitesinin algılanan değer ve tutumsal marka sadakati üzerindeki etkisinin incelendiği bu çalışmada öncelikle örneklem ve ölçeklerine ilişkin bilgilere yer verilmiştir. Elde edilen veriler Şekil-1'de sunulan araştırma model önerisi doğrultusunda analiz edilmiştir.

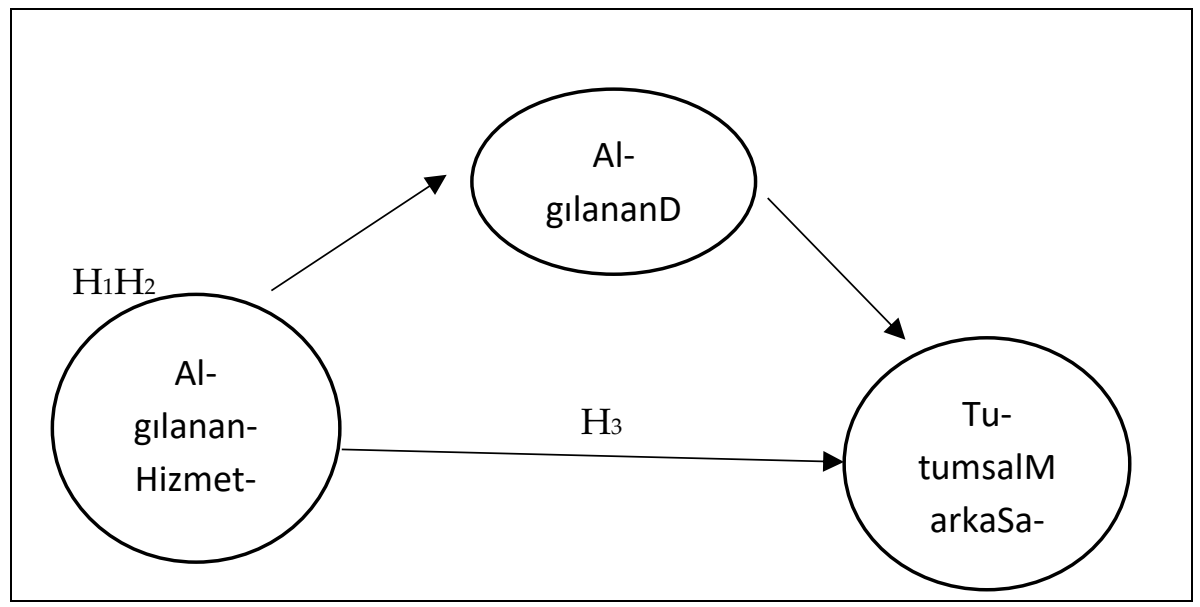

Şekil 1.Araştırma Modeli Önerisi

\section{Evren ve Örneklem}

Araştırmanın evrenini Antalya ve Ankara illerinde faaliyet göstermekte olan beş yıldızlı otel işletmelerini ziyaret eden otel müşterileri oluşturmaktadır. Sayfiye otellerin büyük bölümü Antalya bölgesinde yoğunlaşmıştır. Şehir otelleri ise ülkenin geneline yayılmaktadır (Akdağ vd., 2014: s.262). Çalışma kapsamında Antalya ilinin turizm potansiyeli, Ankara ilinin ise kalabalık nüfusu, uluslararası ve ulusal ticaret potansiyeli, başkent 
olma özelliği gibi nedenler, araştırma evreninin bu illerden seçilmesinde etken olmuştur. Ayrıca, Akdeniz Turistik Otelciler ve İşletmeciler Birliği (AKTOB) verilerine göre Antalya genelinde 403 tane beş yıldızlı otel işletmesi bulunmaktadır. Otel işletmelerinin önemli bir bölümü ilçelerde bulunmaktadır. Bu otellerin nerdeyse tamamı sayfiye otel niteliğinde olup, ülke turizm faaliyetlerinin büyük bölümünü bu otel işletmeleri karşılamaktadır. Anadolu Turizm İşletmecileri Derneği (ATID) 2018 verilerine göre ise Ankara ilinde turizm işletme belgeli 183 otel işletmesi faaliyette bulunmaktadır. Bu otellerin büyük bölümü zincir otel niteliğinde olup Ankara İl Kültür ve Turizm Müdürlüğü web sayfasından edinilen bilgiye göre bu otellerin 22 tanesi beş yıldızlı şehir oteli niteliğindedir. Ancak, Antalya ve Ankara illerinde bulunan beş yıldızı otel işletmelerini ziyaret eden otel müşterilerinin sayısına ilişkin alan yazında herhangi istatistiki bir veriye rastlanılmamaktadır. Dolayısıyla araştırmanın evren sayısı tam olarak bilinmemektedir. Araştırma evreninin çok geniş olması, bütün evrene ulaşmayı zorlaştırmaktadır. Bu nedenle, çalışma kapsamında, maliyet ve zaman kısıtları da dikkate alınarak, evreni temsil edebilecek bir örneklem alınması yoluna başvurulmuştur. Söz konusu araştırma da olasılığa dayalı olmayan örneklem tekniklerden 'kolayda örnekleme' yöntemi uygulanmıştır. Krejcie ve Morgan (1970) tarafından hazırlanan tabloya göre 10.000 üzeri evren için 387 örneklem sayısı yeterli görülmektedir. Bu kapsamda kolayda örnekleme yöntemi ile \% 95 güvenilirlik seviyesinde 460 müşteriye ulaşılmış, ancak 450 anket veri analizi için uygun bulunmuştur.

\section{Veri Toplama Araçları ve Geçerlilik Güvenirlik Analizleri}

Araştırmada yer alan ölçeklerin geçerliliği Keşfedici Faktör Analizi (KFA) ve Doğrulayıcı Faktör Analizi (DFA) ile incelenmiştir (Gürbüz ve Şahin, 2015 , s. 301). KFA ve DFA için verilerin normal dağılım göstermesi gerekmektedir. Normal dağılım için, -3 ve +3 arasındaki çarpıklık ve basıklık değerleri, kabul edilebilir olarak tanımlanmaktadır (Shao, 2002).

Çalışmada kullanılan ölçeklerin güvenirliliği Cronbach alfa katsayısı ile ölçülmüştür. Cronbach alfa değeri 0,70 üzerinde ise anket güvenilir olarak kabul edilmektedir (Hair vd., 2006). 
Algılanan Hizmet Kalitesi Ölçeği: Parasuraman, Zeithaml ve Berry (1988) tarafından kullanılan algılanan hizmet kalitesi ölçeği, Kayaman ve Araslı (2007) tarafından uyarlandığı şekliyle kullanılmıştır (22 soru). Algılanan hizmet kalitesi ölçeğinin boyutlarının güvenilirlik katsayıları; fiziksel özellikler boyutu 0,81 , güvenilirlik boyutu 0,88 , heveslilik boyutu 0,81 , güvence boyutu 0,81 ve empati boyutu 0,82 olarak hesaplanmıştır. Bulunan değişkenlerin çarpıklık ve basıklık değerleri \pm 3 arasındadır. Veriler normal dağılım göstermektedir.

Algılanan hizmet kalitesi ölçeği KMO testi sonunda KMO değeri 0,934 olarak tespit edilmiş olup faktör analizi için örneklem büyüklüğü yeterlidir. Bartlett's Küresellik Testi sonucunda ki-kare değeri 4401,306, serbestlik derecesi değeri (sd) 231 ve p değeri $<0,0001$ bulunmuş olup veriler çok değişkenli normal dağılımdan gelmektedir ve faktör analizine uygundur.

KFA sonucunda 5 boyut elde edilmiştir. Ölçeğin faktör yükleri; fiziksel özellikler boyutu 0,708 ile 0,724, güvenilirlik boyutu 0,659 ile 0,777, heveslilik boyutu 0,701 ile 0,758 , güvence boyutu 0,720 ile 0,740 ve empati boyutu 0,649 ile 0,791 arasında değer aldığı, açıklanan toplam varyansının \% 64,246 olduğu görülmüştür.

Algılanan Değer Ölçeği: European Customer Satisfaction Index (ECSI), tarafından kullanılan algılanan değer ölçeği Chitty vd. (2007) tarafından geliştirildiği şekliyle kullanılmıştır (4 soru). Ölçeğe ait Cronbach alfa katsayısı 0,80 olarak bulunmuştur. Ölçek yeterli güvenilirliğe sahiptir. Bulunan değişkenlerin çarpıklık ve basıklık değerleri \pm 3 arasındadır. Veriler normal dağılım göstermektedir.

KMO testi sonunda KMO değeri 0,801 olarak tespit edilmiş olup faktör analizi için örneklem büyüklüğü yeterlidir. Bartlett's Küresellik Testi sonucunda ki-kare değeri 541,066, serbestlik derecesi değeri (sd) 6 ve p değeri $<0,0001$ bulunmuş olup veriler faktör analizine uygundur. KFA sonucunda tek faktör elde edilmiştir. Bu sonuçlar Chitty vd. (2007) tarafından geliştirilen tek boyutlu yapıyı desteklemektedir. Ölçeğin faktör yüklerinin 0,781 ile 0,807 arasında değer aldığı, oluşan faktörün açıklanan toplam varyansinın \% 63,177 olduğu görülmüştür.

Tutumsal Marka Sadakati Ölçeği: Loken and Jhon (1993), Oliver (1997) ve Beatty, Kahle ve Homer (1988) tarafından geliştirilen ve Back ve Parks (2003), çalışmasında kullandığı ölçekten yararlanılmıştır. Bu kapsamda 
tutumsal marka sadakati ölçeği 9 sorudan oluşmaktadır. Ölçeğin Cronbach alfa katsayısı 0,87 olarak bulunmuştur. Bulunan değişkenlerin çarpıklık ve basıklık değerleri \pm 3 arasındadır. Veriler normal dağılım göstermektedir.

Tutumsal marka sadakati ölçeği KMO testi sonunda KMO değeri 0,930 olarak tespit edilmiş olup faktör analizi için örneklem büyüklüğü yeterlidir. Bartlett's Küresellik Testi sonucunda ki-kare değeri 1445,616, serbestlik derecesi değeri (sd) 36 ve $p$ değeri $<0,0001$ bulunmuş olup veriler faktör analizine uygundur.

KFA sonucunda tek faktör elde edilmiştir. Ölçeğin faktör yükleri 0,679 ile 0,728 arasında değer aldığı, açıklanan toplam varyansının \% 50,395 olduğu görülmüştür.

Yapılan KFA den sonra AMOS paket programı ile doğrulayıcı faktör analizi yapılmıştır. Araştırmada algılanan hizmet kalitesi, algılanan değer ve tutumsal marka sadakati ölçeği ile oluşturulan model test edilmektedir. Yapılan analizler sonucunda uyum iyiliği değerleri aşağıdaki gibi bulunmuştur:

Tablo 1: Model Uyum İndeksleri

\begin{tabular}{lllllll}
\hline & $\chi^{2} / \mathbf{s d}$ & GFI & CFI & NFI & IFI & RMSEA \\
\hline \multirow{2}{*}{ Kriter } & $\leq 5$ & $\geq, 90$ & $\geq, 90$ & $\geq, 90$ & $\geq, 90$ & $\leq, 08$ \\
& 1,093 & 0,93 & 0,99 & 0,92 & 0,99 & 0,014 \\
\hline
\end{tabular}

Modelin sunulan uyum indeksleri incelendiğinde: Ki-kare istatistiğinin serbestlik derecelerine oranı ( $\chi 2 /$ sd) 1,093, yaklaşık hataların ortalama karekökü (RMSEA) 0,014 ve diğer indekslerin belirlenen aralıklarda olduğu tespit edilmiştir. Bu kapsamda modelin iyi uyum gösterdiği belirlenmiştir. Değişkenlerin KFA ve DFA sonucunda ölçeğin geçerliliği için yeterli kanıt toplanmıştır. 


\section{Araştırma Modelinin Test Edilmesi ve Bulgular}

Tablo 2: Demografik Özelliklere İlişkin Frekans Analizi

\begin{tabular}{|c|c|c|c|}
\hline \multicolumn{2}{|c|}{ Demografik Değişkenler } & \multirow{2}{*}{$\begin{array}{c}\mathbf{n} \\
247\end{array}$} & \multirow{2}{*}{$\begin{array}{c}\% \\
54,9\end{array}$} \\
\hline & Erkek & & \\
\hline Cinsiyet & Kadın & 203 & 45,1 \\
\hline \multirow{6}{*}{ Yaş } & $<25$ & 27 & 6,0 \\
\hline & $25-35$ & 74 & 16,4 \\
\hline & $36-45$ & 84 & 18,7 \\
\hline & $46-55$ & 112 & 24,9 \\
\hline & $55-64$ & 102 & 22,7 \\
\hline & $65 \leq$ & 51 & 11,3 \\
\hline \multirow{6}{*}{ Eğitim } & İlköğretim & 6 & 1,3 \\
\hline & Lise & 83 & 18,4 \\
\hline & Ön lisans & 131 & 29,1 \\
\hline & Lisans & 128 & 28,4 \\
\hline & Master & 80 & 17,8 \\
\hline & Doktora & 22 & 4,9 \\
\hline \multirow{2}{*}{ Uyruk } & Yerli & 268 & 59,6 \\
\hline & Yabanc1 & 182 & 40,4 \\
\hline \multirow{3}{*}{ Amaç } & İş & 163 & 36,2 \\
\hline & Tatil & 176 & 39,1 \\
\hline & Diğer & 111 & 24,7 \\
\hline \multirow{4}{*}{$\begin{array}{l}\text { Planlanan } \\
\text { Konaklama } \\
\text { Süresi }\end{array}$} & $<3$ & 97 & 21,6 \\
\hline & $3-5$ & 130 & 28,9 \\
\hline & $6-10$ & 102 & 22,7 \\
\hline & $11 \leq$ & 121 & 26,9 \\
\hline \multirow{3}{*}{$\begin{array}{l}\text { Otel } \\
\text { Tercihi }\end{array}$} & Kendim & 156 & 34,7 \\
\hline & Ofisim & 163 & 36,2 \\
\hline & Diğer & 131 & 29,1 \\
\hline Aynı Otelde & Hiç & 218 & 48,4 \\
\hline Daha Önce & $<3$ & 201 & 44,7 \\
\hline Konaklama Süresi & $3-5$ & 31 & 6,9 \\
\hline \multirow{5}{*}{$\begin{array}{l}\text { Başka Otelde } \\
\text { Konaklama Süresi }\end{array}$} & Hiç & 54 & 12,0 \\
\hline & $<3$ & 184 & 40,9 \\
\hline & $3-5$ & 97 & 21,6 \\
\hline & $6-10$ & 73 & 16,2 \\
\hline & $11 \leq$ & 42 & 9,3 \\
\hline \multirow{4}{*}{$\begin{array}{l}\text { Her yıl, herhangi } \\
\text { bir otelde konaklama } \\
\text { Süresi }\end{array}$} & $<3$ & 52 & 11,6 \\
\hline & $3-5$ & 150 & 33,3 \\
\hline & $6-10$ & 127 & 28,2 \\
\hline & $11 \leq$ & 121 & 26,9 \\
\hline
\end{tabular}


Katılımcıların demografik özelliklerini açılayan bulgulara bakıldığında ankete katılanların \%54,9'u (n: 247) erkek, \%24,9'u (n: 112) 46-55 yaş aral1ğındadır. Katılımcıların \%29,1'i (n: 131) ön lisans mezunu ve \%59,62's1 yerli turistlerden oluşmaktadır.

Araştırmanın temel hipotezleri doğrultusunda kavramsal ilişkiler elde edilen veriler çerçevesinde irdelenmiştir. Araştırmada değişkenler arasındaki ilişkilerin ortaya çıarılması amacıyla korelasyon analizi yapılmış, analiz sonuçları Tablo-3'te sunulmuştur.

Tablo 3: Korelasyon Analizi Sonuçlan

\begin{tabular}{llllllll}
\hline & $\mathbf{1}$ & $\mathbf{2}$ & $\mathbf{3}$ & $\mathbf{4}$ & $\mathbf{5}$ & $\mathbf{6}$ & $\mathbf{7}$ \\
\hline 1. F. Özellikler & 1 & & & & & & \\
2. Güvenilirlik &, $573^{* *}$ & 1 & & & & & \\
3. Heveslilik &, $452^{* *}$ &, $536^{* *}$ & 1 & & & & \\
4. Güvence &, $411^{* *}$ &, $510^{* *}$ &, $453^{* *}$ & 1 & & & \\
5. Empati &, $442^{* *}$ &, $448^{* *}$ &, $468^{* *}$ &, $510^{* *}$ & 1 & & \\
6. A. Değer &, $429^{* *}$ &, $464^{* *}$ &, $436^{* *}$ &, $473^{* *}$ &, $666^{* *}$ & 1 & \\
7. T. M. Sadakati &, $404^{* *}$ &, $426^{* *}$ &, $460^{* *}$ &, $436^{* *}$ &, $574^{* *}$ &, $577^{* *}$ & 1 \\
\hline
\end{tabular}
${ }^{*} p<0.05,{ }^{* *} p<0.01,{ }^{* * *} p<0.001$

Tablo-4'te sunulduğu üzere korelasyon katsayıları dikkate alındığında algilanan hizmet kalitesi boyutları ile algılanan değer ve tutumsal marka sadakati değişkenleri arasında anlamlı ilişkilerin bulunduğu görülmektedir.

Tablo 4: Yapısal Eşitlik Modeli Regresyon Ağırlıkları

\begin{tabular}{|c|c|c|c|c|}
\hline Değişken & Tahmin & Std. Hata & Kritik Oran & $\mathbf{P}$ \\
\hline Hia F.Özellikler $\longrightarrow$ A. Değer & ,045 & 061 & 658 &, 510 \\
\hline $\mathrm{H}_{1 \mathrm{~b}}$ Güvenilirlik $\longrightarrow$ A. Değer & 119 & 060 & 1,631 & 103 \\
\hline $\mathrm{H}_{1 \mathrm{c}}$ Heveslilik $\longrightarrow$ A. Değer & 011 & 064 & 160 & 873 \\
\hline $\mathrm{H}_{1 \mathrm{~d}}$ Güvence $\longrightarrow$ A. Değer & 059 &, 066 & 872 & ,383 \\
\hline$\rightarrow$ A. Değer & 688 & ,098 & 8,335 & $* * *$ \\
\hline $\mathrm{H}_{3 а}$ F.Özellikler $\longrightarrow$ T.M.Sadakati & 030 & 052 & 454 & 650 \\
\hline $\mathrm{H}_{3 \mathrm{~b}}$ Güvenilirlik $\longrightarrow$ T.M.Sadakati &,- 057 & 052 &,- 793 & 428 \\
\hline $\mathrm{H}_{3 \mathrm{c}}$ Heveslilik $\longrightarrow$ T.M.Sadakati & 132 & ,055 & 2,026 & ,043 \\
\hline $\mathrm{H}_{3 \mathrm{~d}}$ Güvence $\longrightarrow$ T.M.Sadakati & 284 & 059 & 4,152 & $* * *$ \\
\hline$\longrightarrow$ T.M.Sadakati & 164 & 105 & 1,611 & 107 \\
\hline$\longrightarrow$ T.M.Sadakati & 332 & ,088 & 3,313 & *** \\
\hline
\end{tabular}


Hipotezlerin test edilebilmesi için yol analizi yapılmıştır ve ölçülmesi hedeflenen " $\mathrm{H}_{1 \mathrm{a}}, \mathrm{H}_{1}, \mathrm{H}_{1 c}, \mathrm{H}_{1 \mathrm{~d}}, \mathrm{H}_{1 \mathrm{e}}, \mathrm{H}_{2}, \mathrm{H}_{3}, \mathrm{H}_{3}, \mathrm{H}_{3}, \mathrm{H}_{3 \mathrm{~d}}, \mathrm{H}_{3 \mathrm{e}}$ ” hipotezi test edilmiştir.

Yol analizi sonuçlarına göre, model kabul edilebilir uyum sergilemektedir ( $\chi^{2} / d f:$ 1,093; p<0.001; RMSEA: 0.014; NFI: 0.92; CFI: 0,99; IFI: 0,99; GFI: 093).

Araştırma hipotezleri kapsamında yapılan yol analizi sonuçları incelendiğinde algilanan hizmet kalitesinin empati boyutunun algılanan değere, heveslilik ve güvence boyutunun ise tutumsal marka sadakatine olumlu yönde anlamlı bir etkisinin olduğu görülmektedir. Ayrıca algılanan değerin tutumsal marka sadakati üzerinde de bir etkisinin olduğu yol analizi sonuçlarına göre tespit edilmiştir. Bu kapsamda algılanan hizmet kalitesinin empati boyutunun algılanan değer ile; algılanan hizmet kalitesinin heveslilik ve güvence boyutunun tutumsal marka sadakati ile ve algılanan değerin tutumsal marka sadakati ile arasındaki ilişki istatistiksel olarak anlamlı bulunmuştur $(\mathrm{p}<0,05)$. Bu etkiler arasında pozitif yönlü bir ilişki vardır. Dolayısıyla araştırma kapsamında oluşturulmuş "Hıe: Algılanan hizmet kalitesinin empati boyutu algilanan değeri pozitif ve doğrudan etkilemektedir.", "H2: Algilanan değer, tutumsal marka sadakatini pozitif ve doğrudan etkilemektedir.","Hзc:Algilanan hizmet kalitesinin heveslilik boyutu tutumsal marka sadakatini pozitif ve doğrudan etkilemektedir." ve "H3d: Algllanan hizmet kalitesinin güvence boyutu tutumsal marka sadakatini pozitif ve doğrudan etkilemektedir." hipotezleri kabul edilmiştir. Bunun yanı sıra " $\mathrm{H}_{1 \mathrm{a}}, \mathrm{H}_{1 \mathrm{~b}}, \mathrm{H}_{1 c}$, $\mathrm{H}_{1 \mathrm{~d}}, \mathrm{H}_{3 \mathrm{a}}, \mathrm{H}_{3 \mathrm{~b}}$ ve $\mathrm{H}_{3 \mathrm{e}}$ " hipotezleri yapılan yol analizi sonuçlarına göre kabul edilmemiştir.

\section{Değerlendirme ve Sonuç}

Çalışma algılanan hizmet kalitesi, algılanan değer ve tutumsal marka sadakati arasındaki ilişkileri belirlemek amacıyla hazırlanmıştır. Ankara ve Antalya'da faaliyet gösteren beş yıldızlı sayfiye ve şehir otellerini ziyaret eden müşteriler üzerine yapılmıştır. Genel olarak, ölçüm sonuçları güvenilirlik ve geçerlilik açısından kabul edilebilir niteliktedir. Korelasyon ve yol analizi teknikleri ile bu sonuçlar kısmen desteklenmiştir. 
Gerçekleştirilen analiz sonuçlarına göre, "H1e: Algılanan hizmet kalitesinin empati boyutu algılanan değeri pozitif ve doğrudan etkilemektedir.", "H2: Algilanan değer, tutumsal marka sadakatini pozitif ve doğrudan etkilemektedir.","Hzc:Algilanan hizmet kalitesinin heveslilik boyutu tutumsal marka sadakatini pozitif ve doğrudan etkilemektedir." ve"H3d: Algılanan hizmet kalitesinin güvence boyutu tutumsal marka sadakatini pozitif ve doğrudan etkilemektedir." hipotezleri kabul edilmiştir.

Algılanan hizmet kalitesinin empati boyutu algılanan değeri pozitif ve doğrudan etkilemektedir. Çalışmamızda elde edilen sonuç, alan yazını destekler niteliktedir. Uluslararası alan yazında algılanan hizmet kalitesi ve algilanan değeri inceleyen birçok yazar (Ladhari ve Morales, 2008; Leonnard, 2018; Raza vd., 2012; Choi vd., 2018; Ashraf vd., 2018; Lai, 2014; Hapsari vd., 2016; Milfelner vd., 2011; Chen ve Chen, 2010), gerçekleştirdikleri çalışmalarda algılanan hizmet kalitesi ile algılanan değer arasında güçlü ilişki tespit etmişlerdir. Gerçekleştirilen çalışma kapsamında ayrıca algilanan değerin tutumsal marka sadakati üzerinde pozitif ve doğrudan bir etkiye sahip olduğu tespit edilmiştir. Otelcilik sektörü de dahil değişik hizmet sektörlerinde gerçekleştirilen çalışmalar (Oh, 1999; Cronin, 2000; Chitty vd., 2007; Şener ve Behdioğlu, 2013; Altunel ve Günlü, 2015; Sweeney ve Soutar, 2001; El-Adly, 2018; Krasna, 2008; Çetintürk, 2017) ulaş1lan sonuçla benzer niteliktedir. Çalışma kapsamında son olarak, algılanan hizmet kalitesinin heveslilik ve güvence boyutunun tutumsal marka sadakati üzerinde pozitif ve doğrudan bir etkisi olduğu tespit edilmiştir. Bu değer, alan yazında gerçekleştirilen çalışmalarla benzer bir sonuç ortaya çıkarmıştır (Usta ve Memiş, 2009; Ertürk, 2011; Kayaman ve Araslı, 2007; Alhaddad, 2015; Souki ve Filho, 2008; Alexandris, vd., 2006). Öte yandan, Kayaman ve Araslı (2007) ve Kim vd. (2008), hizmet kalitesinin sadece fiziksel özellikler ve heveslilik boyutlarının marka sadakati üzerinde etkisinin olduğunu, diğer boyutlarda böyle bir etkiye rastlanılmadığını rapor etmişlerdir. Han vd. (2008), Çin' de iki otel işletmesinde gerçekleştirdikleri çalışmada, hizmet kalitesinin tutumsal marka sadakatinin ilk aşaması olan bilişsel marka sadakati boyutunda etki yarattığını, diğer bütünleşik sadakat boyutlarında ise herhangi bir etkiye rastlanılmadığını rapor etmişlerdir. Jasinskas vd. (2016), Litvanya Kaunas bölgesinde dört yıldızlı otellerde konaklayan 205 turist üzerinde gerçekleştirdikleri çalışmada, turist- 
lerin beklenen kalite ile algıladıkları kalite arasındaki farkın az olması durumunun marka sadakat düzeylerinde belirgin bir etki yarattığını ortaya koymuştur. Günaydın (2015), Bodrum Aegean Dream Hotel' de hizmet kalitesi ile müşteri sadakati arasında güçlü bir ilişki tespit etmiştir. Ashraf vd. (2018), hastane, otel, eğitim ve bankacıllk hizmet sektörlerinde 440 müşteri ile gerçekleştirdikleri çalışmada algılanan hizmet kalitesi ve alg1lanan değerin marka sadakatine etkisini araştırmışlar, hizmet kalitesinin ve algılanan değerin marka sadakatini etkilediğini, müşteri tatmininin aracı etkiye sahip olduğunu belirtmişlerdir.

Sonuç olarak bakıldığında çalışmamızda elde edilen sonuçlar ulusal ve uluslararası yazında yapılan çalışmaları desteklemektedir. Son yıllarda, marka sadakatine ilişkin çalışmaların sayısı arttıkça, marka sadakatinin belirleyicisi olarak kabul edilen hizmet kalitesi ve algılanan değer vs. gibi kavramlara yönelik çalışmaların sayısı da artmaktadır. Bu kavramların, özellikle turizm endüstrisi gibi yaşam döngüsünün olgunluk aşamasında olduğu düşünülen hizmet sektörlerinde marka sadakatine yönelik etkilerinin incelenmesindeki en önemli etkenin piyasa rekabet koşulları olduğu düşünülebilir. Zira olgunluk aşaması, rakiplerin sayısının olabildiğince arttığ1 ve rekabetin şiddetli yaşandığ1 bir evredir (Ergin, 1999, s.17). Mamul hayat eğrisinin her aşamasında olduğu gibi olgunluk aşamasında da markalaşmaya yönelik stratejilerin benimsenmesi ve uygulanması gerekli gözükmektedir (Somaklar, 2006, s.113). Bu yüzden marka sadakati belirleyicilerine yönelik çalışmaların sayısının değişik hizmet sektörlerinde arttırılması önemli gözükmektedir. Bu çalışma zaman ve maliyet kısıtları dikkate alınarak Antalya ve Ankara illerinde gerçekleştirilmiştir. Daha sonraki çalışmalarda ülkenin farklı bölgelerinde konaklayan turistlere ulaşılarak çalışma kapsamının genişletilmesi yararlı olacaktır. Ayrıca, alan yazına yönelik incelemelerde marka sadakati üzerinde etkisi olan marka kavramı ile ilişkili (imaj, tatmin vs.) değişik kavramlar göze çarpmaktadır. Sonraki çalışmalarda bu kavramalara odaklanılması alan yazına değişik bakış açıları kazandıracağı düşünülmektedir. 


\title{
EXTENDED ABSTRACT
}

\section{Investigation of the Effects of Perceived Service Quality on Perceived Value and Attitudinal Brand Loyalty: Example of 5-Star Resort and City Hotels}

\author{
Bülent Demirağ - Yakup Durmaz
}

Hasan Kalyoncu University

The strengthening of the perception of the importance of the brand in terms of companies, in recent years, as in almost every sector in the tourism sector is observed in many studies (Mason et al., 2006; Mattila, 2006; OğlNeill et al., 2006). A significant portion of these studies focused on the premise of brand loyalty and brand loyalty. There are detailed studies about the perceived quality of service, perceived value concepts which are the pioneers of brand loyalty and brand loyalty in the studies towards literature (Back and Parks, 2003; Han et al., 2008; Chitty et al., 2007; Kayaman and Arasl1, 2007). It is possible to multiply the number of these studies. The concept of brand loyalty and many brand components which are thought to have direct and indirect effects on this concept are being studied in different cultures and geographies (Brodie et al., 2009; Cronin et al., 2000; Dick and Basu, 1994; Oliver, 1997).

Perceived service quality is an assessment of the difference between consumers' expectations and perceptions. Expectations are reflected in requests that are believed by consumers to provide a service provider. If the expectations are not in line with the perceived quality, negative evaluations of the product occur. However, if the perceived quality exceeded the expectations, the company was acquired (Lovelock and Wright, 2007). The perceived value is an assessment of the consumer's perceived benefit and payment. In general, consumers cover costs (purchase price, purchase costs, installation), while perceived benefits are the benefits of combinations of physical and abstract properties of the product / service (Varki and Colgate, 2001, p. 234). Customers generally do not evaluate the benefits 
and costs accurately or objectively, but act on the perceived value of the product. Therefore, firms should be able to control the customer's perceptions of quality and value judgments (Baker and Fulford, 2016, p. 76). Brand loyalty is an important strategy for developing a sustainable competitive advantage for any business (Dick and Basu, 1994). Newman and Werbal (1973, p. 405), based on a similar definition of trust based on loyalty assessment. Accordingly, the prerequisite for the loyalty of the brand is that customers who use the brand exhibit purchasing behavior for experience in the use of repetitive products / services. Oliver (1997) states that brand loyalty is composed of three dimensions: cognitive, affective and conative.

\section{Objective of the Study}

Based on the literature review and the above-mentioned variables, three basic hypotheses have been constructed within the framework of the conceptual model in order to pursue the objectives of the research.

- H1a. The physical characteristics of the perceived service quality affect the perceived value positively and directly.

- H1b. The reliability dimension of the perceived service quality affects the perceived value positively and directly.

- H1c. The enthusiasm of the perceived quality of service affects the perceived value positively and directly.

- H1d. The assurance dimension of the perceived service quality affects the perceived value positively and directly.

- H1e. The emphathic dimension of perceived service quality affects the perceived value positively and directly.

- H2. Perceived value affects positively brand loyalty positively and directly.

- H3a. The physical characteristics of perceived service quality affect brand loyalty positively and directly.

- H3b. The reliability dimension of the perceived service quality affects brand loyalty positively and directly.

- H3c. The enthusiasm of perceived service quality affects brand loyalty positively and directly. 
- H3d. The assurance dimension of perceived service quality affects brand loyalty positively and directly.

- H3e. The empathic dimension of perceived service quality affects brand loyalty positively and directly.

\section{Method}

The perceived service quality scale used by Parasuraman, Zeithaml and Berry (1988) was used as adapted by Kayaman and Araslı (2007) (22 questions). Reliability coefficients of the dimensions of the perceived service quality scale; The physical properties were calculated as 0.81 , the reliability size was 0.88 , the enthusiasm size was 0.81 , the assurance size was 0.81 and the empathy size was 0.82 . The skewness and kurtosis values of the variables found are between \pm 3 . The data show normal distribution. The perceived value scale used by the European Customer Satisfaction Index (ECSI) is used by Chitty et al. (2007) was used (4 questions). The Cronbach alpha coefficient of the scale was found to be 0.80 . The scale has sufficient reliability. The skewness and kurtosis values of the variables found are between \pm 3 . The data show normal distribution. Lokan and Jhon (1993), Oliver (1997) and Beatty, Kahle and Homer (1988) developed by Back and Parks (2003), used in the study of the scale. In this context, the attitudebased brand loyalty scale consists of 9 questions. The Cronbach alpha coefficient of the scale was found to be 0.87 . The skewness and kurtosis values of the variables found are between \pm 3 . The data show normal distribution.

\section{Results}

According to the results of the analysis performed, eves H1e: The empathy dimension of the perceived service quality affects the perceived value positively and directly. Marka,, H2: Perceived value affects brand loyalty positively and directly. An, emp H3c: The enthusiasm of perceived service quality is positive "and H3d: The assurance dimension of perceived quality of service affects positively brand loyalty positively and directly, hypothesis has been accepted. 
In conclusion, the results of our study support the studies conducted in the national and international literature. It is important to increase the number of studies on brand loyalty determinants in different service sectors. This study was carried out in Antalya and Ankara provinces considering time and cost constraints. In later studies it will be useful to expand the scope of work by reaching out to tourists staying in different parts of the country. In addition, different concepts related to the concept of brand (image, satisfaction, etc.) which have an effect on brand loyalty are observed in investigations related to the literature. In later studies, it is thought that focusing on these concepts will bring different perspectives to the literature.

\section{Kaynakça / References}

Akdağ, G., Güler, O., Demirtaş, O., Dalgiç, A. ve Yeşilyurt, C. (2014). Turizm ve çevre ilişkisi: Türkiye'deki yeşil otellerin gözünden yeşil otelcilik uygulamalari üzerine bir değerlendirme. Coğrafyacılar Derneği Uluslararası Kongresi Bildiriler Kitabı, Muğla Sıtkı Koçman Üniversitesi, Muğla, 4-6 Haziran 2014.

Alexandris, K., Kouthouris, C. ve Meligdis, A. (2006). Increasing customers' loyalty in a skiing resort: The contribution of place attachment and service quality. International Journal of Contemporary Hospitality Management, 18(5), 414-425.

Alhaddad, A.A. (2015). Perceived quality:Brand image and brand trust as determinants of brand loyalty. Quest Journals Journal of Research in Business and Management, 3(4), 1-8.

Altunel, M.C. ve Günlü, E. (2015). Deneyimleme kalitesi: Alg1lanan değer ve tatminin müze ziyaretçilerinin tavsiye etme eğilimi üzerindeki etkisi.Anatolia: Turizm Araştırmaları Dergisi,26(2), 191-206.

Arpac1, Ö. ve Batman, O. (2015). Specifying the relationship among perceived service quality: Customer loyalty and customer value of the halal hotels in high season. Turizm ve Arastırma Dergisi, 4(1),29-45.

Ashraf, S., Ilyas, R., Imtiaz, M. ve Ahmad, S. (2018). Impact of service quality, corporate image and perceived value on brand loyalty with presence and absence of customer satisfaction: A study of four service sectors of Pakistan. International Journal of Academic Research in Business and Social Science, 8(2), 452-474. 
Back, K. (2005). The effects of image congruence on customers' brand loyalty in the upper middle-class hotel industry. Journal of Hospitality E Tourism Research, 29(4), 448-467.

Back, K. ve Parks, S. C. (2003). A brand loyalty model involving cognitive, affective, and conative brand loyalty and customer satisfaction. Journal of Hospitality \& Tourism Research, 27(4), 419-435.

Baker, D. M. ve Fulford, M. D. (2016). Cruise passengers' perceived value and willingness to recommend. Tourism \& Management Studies, 12(1), 74-85.

Becker, P. (2014). The different types of tourists and their motives when visiting Alaska during the Iditarod, Master Thesis, in Tourism Studies, The Arctic University of Norway, Norway.

Bhattacharya, S. ve Singh, D. (2008). The emergence of hierarchy in customer perceived value for services: A grounded analysis. Journal of American Academy of Business, 13, 65-71.

Bowen, J. T. ve Shoemaker, S. (2003). Loyalty: A strategic commitment. Cornell Hotel and Restaurant Administration Quarterly, 44(5/6), 31-46.

Bozdağ, N., Atan, M. ve Altan, Y. (2003). Hizmet Sektöründe Toplam Hizmet Kalitesinin SERVQUAL Analizi ile Ölçümü ve Bankacılık Sektöründe Bir Uygulama. VI. Ulusal Ekonometri ve İstatistik Sempozyumu, Gazi Üniversitesi, Ankara, 29-30 Mayı.

Bresciani, S., Thrassou, A. ve Vrontis, D. (2015). Determinants of performance in the Italian hotel industry:An empirical analysis of Italy. Global Business and Economics Review, 17(1), 19-34.

Brodie, R. J. Whittome, J. R. ve Brush, G. J. (2009). Investigating the service brand: A customer value perspective. Journal of Business Research, 62(3), 345-355.

Casadesus, M., Viadiu, M. F. ve Saizarbitoria, I.H. (2002). Quality service of ISO 9000 consultants. International Journal of Quality and Reliability Management, 19 (8/9), 998-1013.

Chen, C.F. ve Chen, F.S. (2010). Experience quality, perceived value, satisfaction and behavioral intentions for heritage tourists. Tourism Management, 31(1), 29-35.

Chitty, B. , Ward, S. ve Chua, C. (2007). An application of the ECSI model as a predictor of satisfaction and loyalty for backpacker hostels. Marketing Intelligence \& Planning,25, 563-580. 
Choi, C., Greenwell, T.C. ve Lee, K. (2018). Effects of service quality, perceived value, and consumer satisfaction on behavioral intentions in virtual golf. Journal of Physical Education and Sport, 18(3),14591468.

Cunningham, R. M. (1956). Brand loyalty:What, where, how much?. Harvard Business Review, 34(1), 116-128.

Çetiner, E. (2002). Konaklama işletmelerinde muhasebe uygulamaları. Ankara: Gazi Kitabevi.

Çetintürk, İ. (2017). Müşteri değeri, müşteri tatmini ve marka sadakati: Üniversite sosyal tesisleri üzerine bir araştırma. Seyahat ve Otel İşletmeciliği Dergisi, 14(2), 93-109.

Day, G. S. (1969). A two-dimensional concept of brand loyalty. Journal of Advertising Research, 9(3), 29 - 35.

Dick, A. S. ve Basu, K. (1994). Customer loyalty: Toward an integrated conceptual framework. Journal of Academy of Marketing Science, 22(2), 99-113.

Dinç, Y. (1999). Sayfiye otel işletmelerinde boş zaman ve rekreasyon değerlendirmelerinin hizmet satışların arttırmaya yönelik etkisi:Örnek bir araştırma, Yüksek Lisans Tezi, Balıkesir Üniversitesi Sosyal Bilimler Enstitüsü Turizm İşletmeciliği ve Otelcilik Anabilim Dalı, Balıkesir.

El-Adly, M.I. (2018). Modelling the relationship between hotel perceived value, customer satisfaction, and customer loyalty. Journal of Retailing and Consumer Services, Article in Press, 45,1-11. https://doi.org/10.1016/j.jretconser.2018.07.007.

Emir, O. (2007). Otel işletmelerinde müşterilerin hizmet beklentileri ve memnuniyet (tatmin) düzeylerinin değerlendirilmesi: Antalya'da bir araştırma. Doktora Tezi, Afyon Kocatepe Üniversitesi Sosyal Bilimler Enstitüsü, Afyonkarahisar.

Ertürk, M. (2011). Türkiye'deki otel işletmelerinde hizmet kalitesinin ölçülmesine yönelik bir alan araştırması. Doktora Tezi, Gazi Üniversitesi Eğitim Bilimleri Enstitüsü Turizm İşletmeciliği Eğitimi Anabilim Dalı, Ankara.

Gale, B. T. (1994). Managing customer value: Creating quality and service that customers can see. New York: The Free Press. 
Genç, E. ve Erdoğan, E. (2013). Otel İşletmelerinde ilişkisel pazarlama uygulamaları: Zonguldak, Karabük ve Bartın illerinde bir araştırma. Afyon Kocatepe Üniversitesi İ̈BF Dergisi, 15(2), 195-216.

Güçer, E. ve Kement, Ü. (2015). Ekoturizm kapsamında seyahat eden tüketicilerin çevreye duyarlı davranışlarının incelenmesi: Ayder örneği, Gümüşhane Üniversitesi Sosyal Bilimler Elektronik Dergisi, 14, $70-82$.

Günaydın, Y. (2015). Hizmet kalitesinin müşteri sadakatine etkisi: Aegean Dream Hotel örneği,International Journal of Social Sciences and Education Research, 1(1), 16-34.

Han, X. , Kwortnik, R. J. ve Wang, C. (2008). Service loyalty: An integrative model and examination across service contexts. Journal of Service Research, 11, 22-42.

Hapsari, R., Clemes, M. ve Dean, D. (2016). The mediating role of perceived value on the relationship between service quality and customer satisfaction: Evidence from Indonesian Airline passengers. Procedia Economics and Finance, 35, 388-395.

Harris, L. C. ve Goode, M. M. (2004). The four levels of loyalty and the pivotal role of trust: A study of online service dynamics. Journal of Retailing, 80(2), 139-158.

Hinson, R. ve Chinje, N. (2016). Extending the four-stage brand loyalty framework in African Telecoms. African Journal of Business and Economic Research (AJBER),2(3), 53-82.

Holbrook, M.B. (1996). Customer value CA framework for analysis and research. Advances in Consumer Research (Special Session Summary), $23,138-142$.

Jacoby, J. ve Chestnut, R. W. (1978). Brand loyalty: Measurement and management, New York:Wiley.

Jasinskas, E., Streimikiene, D., Svagzdiene, B. ve Simanavicius, A. (2016). Impact of hotel service quality on the loyalty of customers. Economic Research-Ekonomska Istraživanja, 29(1), 559-572.

Jones, T. ve Taylor, S. F. (2007). The conceptual domain of service loyalty: How many dimensions? The Journal of Services Marketing, 21(1), 3651. 
Kandampully, J. and Hu, H. (2007). Do hoteliers need to manage image to retain loyal customers? International Journal of Contemporary Hospitality Management, 19(6), 435-443.

Kayaman, R. ve Arasli, H. (2007). Customer based brand equity: Evidence from the hotel industry. Managing Service Quality, 17, 92-109.

Kılıç, G. ve Öztürk, Y. (2010). Kariyer yönetim sistemi ve örgütsel bağlılık arasındaki ilişki: Beş yıldızlı otel işletmelerinde bir araştırma. Ege Akademik Bakış, 10(3), 981-1001.

Kim, W.G., Jin-Sun, B. and Kim, H.J. (2008). Multidimensional customerbased brand equity and its consequences in midpriced hotels. Journal of Hospitality \& Tourism Research, 32, 235-254.

Kozak, N. (2008). Turizm pazarlaması, Detay Yayıncllı: Ankara.

Krasna, T. (2008). The influence of perceived value on customer loyalty in Slovenian hotel industry. Turizam, 12-15.

Krejcie, R. V. ve Morgan, D. W. (1970). Determining sample size for research. Education and Psychological measurement, 30, 607-610.

Ladhari, R. ve Morales, M. (2008). Perceived service quality, perceived value and recommendation: A study among Canadian public library users, Library Management, 29(4/5), 352-366.

Lai, I.K.W. (2014). The role of service quality, perceived value, and relationship quality in enhancing customer loyalty in the travel agency sector.Journal of Travel \& Tourism Marketing,31(3), 417-442.

Lee, J. , Graefe, A. R. ve Burns, R. C. (2007). Examining the antecedents of destination loyalty in a forest setting Leisure Sciences, 29(5), 463481.

Leonnard, S.E. (2018). Perceived service quality, perceived value for money, satisfaction and repurchase intention: An evaluation on private university services. International Journal of Commerce and Finance, 4(1), 40-51.

Lovelock, C. and Wright, L. (2007). Principles of service marketing and management(5. ed), New Jersey: Prentice Hall.

Mason, D., Tideswell, C. ve Roberts, E. (2006). Guest perceptions of hotel loyalty. Journal of Hospitality \& Tourism Research, 30(2), 191-206.

Mattila, A. S. (2006). How affective commitment boosts guest loyalty and promotes frequent-guest programs. Cornell Hotel and Restaurant Administration Quarterly, 47, 174-181. 
Milfelner, B., Snoj, B. ve Pisnik Korda, A. (2011). Measurement of perceived quality, perceived value, image and satisfaction interrelations of hotel services: Comparison of tourists from Slovenia and Italy. Drus. Istraz. Zagreb God. 20 (2011), BR. 3 (113), STR. 605-624.

Nasution, H. N. ve Mavondo, F. T. (2008). Customer value in the hotel industry: What managers believe they deliver and what customer experience. International Journal of Hospitality Management, 27(2), 204-213.

Newman, J.W. ve Werbel, R.A. (1973). Multivariate analysis of brand loyalty for major household appliances. Journal of marketing research, 10, 404-409.

Odin, Y., Odin, N. ve Valette-Florence, P. (2001). Conceptual and operational aspects of brand loyalty: An empirical investigation. Journal of Business Research, 53(2), 75-84.

Oh, H. (1999). Service quality, customer satisfaction, and customer value: A holistic perspective. International Journal of Hospitality Management, 18(1), 67-82.

Oliver, R.L. (1997). Loyalty and profit: long-term effects of satisfaction. Satisfaction: A Behavioural Perspective on the Consumer, McGraw-Hill Companies, Inc., New York, NY.

Oliver, R. L. (1999). Whence consumer loyalty? Journal of Marketing, Fundamental Issues and Directions for Marketing, 63(4), 33-44.

O'Neill, J. W. ve Xiao, Q. (2006). The role of brand affiliation in hotel market value. Cornell Hotel and Restaurant Administration Quarterly, 47, 210-223.

Parasuraman, A., Zeithaml, V.A. ve Berry, L.L. (1985). A conceptual model of service quality and its implications for future research. Journal of Marketing, 49(4), 41-50.

Parasuraman, A., Zeithaml, V.A. ve Berry, L.L. (1988). Servqual: A multiple-item scale for measuring consumer perceptions of service quality. Journal of Retailing, 64(1), 12-40.

Park, C., Jaworski, B. J. ve Maclnnis, D. J. (1986). Strategic brand conceptimage management. Journal of Marketing, 50(4), 135-145.

Petrick, J.F. (2004). The roles of quality, value, and satisfaction in predicting cruise passengers' behavioral intentions. Journal of Travel Research, 42, 397-407. 
Raza, M.A., Siddiquei, A.N., Awan, H.M. ve Bukhari, K. (2012). Relationship between service quality, perceived value, satisfaction and revisit intention in hotel industry. Interdisciplinary Journal Of Contemporary Research In Business, 4(8), 788-805.

Saraniemi, S. ve Kylänen, M. (2011). Problematizing the concept of tourism destination: An analysis of different theoretical approaches. Journal of Travel Research,50(2), 133 - 143.

Seyidov, J. ve Adomaitienè, R. (2016). Factors influencing local tourists' decision-making on choosing a destination: A case of Azerbaijan. Ekonomika, 95(3), 112-127.

Sirdeshmukh, D., Singh, J. ve Sabol, B. (2002). Consumer trust, value, and loyalty in relational exchanges. The Journal of Marketing, 66, 15-37.

Souki, G.Q. ve Filho, C.G. (2008). Perceived quality, satisfaction and customer loyalty: An empirical study in the mobile phones sector in Brazil. Int. J. Internet and Enterprise Management, 5(4), 298-312.

Suhartanto, D. ve Noor, A. (2013). Attitudinal loyalty in the budget hotel industry: What are the important factors? Journal Of Tourism, Hospitality \& Culinary Arts, 5(2), 64-74.

Sweeney, J. C. ve Soutar, G. N. (2001). Consumer perceived value: The development of a multiple item scale. Journal of Retailing, 77, 203-220.

Şener, H.Y. ve Behdioğlu, S. (2013). Müşteri sadakati oluşturmada müşterinin algıladığı değer, tatmin ve rakip işletmeye geçme maliyeti: Bir spor merkezinde istatiksel uygulama. Selçuk Üniversitesi Sosyal Bilimler Enstitüsü Dergisi, 30, 165-180.

Tsai, H., Song, H. Y. ve Wong, K. K. F. (2009). Tourism and hotel competitiveness research. Journal of Travel \& Tourism Marketing,26 (5-6), 522-546.

Tucker, W. T. (1964). The development of brand loyalty. Journal of Marketing Research, 1, 32-35.

Tunç, A. ve Sevin, D. (2000). An analysis of business ethics in accommodation sector on tourism industry. Challanges for business administrators in the new milennium. Uluslararası Kongre Tebliği. Çanakkale On Sekiz Mart Üniversitesi-Silesian University, 1-3 Haziran 2000, Gökçeada, Çanakkale.756-765. 
Usta, R. ve Memiş, S. (2009). Hizmet kalitesi ve marka bağlllığı arasındaki ilişki üzerine müşteri tatmininin aracılık etkisi. Atatürk Üniversitesi İktisadi ve İdari Bilimler Dergisi, 23(4), 87-108.

Ünüvar, Ş. (2008). Konaklama işletmelerinde reklam kampanyaları uygulamaları: stratejik bir yaklaşım. Doktora Tezi, Selçuk Üniversitesi Sosyal Bilimler Enstitüsü Halkla İlişkiler ve Tanıtım Anabilim Dalı Reklam ve Tanitım Bilim Dalı, Konya.

Varki, S. ve Colgate, M. (2001). The role of price perceptions in an integrated model of behavioral intentions. Journal of Service Research, 3(3), 232-240.

Wang, Y. , Lo, H. P., Chi, R. ve Yang, Y. (2004). An integrated framework for customer value and customer-relationship-management performance: A customer-based perspective from China. Managing Service Quality, 14(2/3), 169-182.

Wang, B., Yang, Z., Han, F. ve Shi, H. (2016). Road trip in China: The mediation effect of perceived value and tourist satisfaction on the relationship between destination image and loyalty. Preprints (www.preprints.org), doi:10.20944/preprints201611.0050.v1. Erişim Tarihi: 05.12.2018.

Yüksel, A., Yüksel, F. ve Bilim, Y. (2010). Destination attachment: Effects on customer satisfaction and cognitive, affective and conative loyalty. Tourism Management, 31, 274-284.

Zeithaml, V. A. (1988). Consumer perceptions of price, quality, and value: A means-end model and synthesis of evidence. Journal of Marketing, 52(3), 2-22.

Zeithaml, V.A., Parasuraman, A. ve Berry, L.L. (1990). Delivering quality service: Balancing customer perceptions and expectations. New York, NY: The Free Press.

Zeithaml, V. A., Berry, L. L. ve Parasuraman, A. (1996). The behavioral consequences of service quality. Journal of Marketing, 60(2), 31-46.

Zeithaml, V. A., Bitner, M. J. ve Gremler, D. D. (2006). Services marketing: Integrating customer focus across the firm (4 ed.). Boston: McGrawHill Irwin. 


\section{Kaynakça Bilgisi / Citation Information}

Demirağ, B. ve Durmaz, Y.(2019).Algılanan hizmet kalitesinin algılanan değer vetutumsal marka sadakati üzerindeki etkisinin incelenmesi: 5 yıldızlı sayfiye ve şehir otelleri örneği. OPUS-Uluslararası Toplum Araştırmaları Dergisi, 11(18), 693-726. DOI: 10.26466/opus.542994 